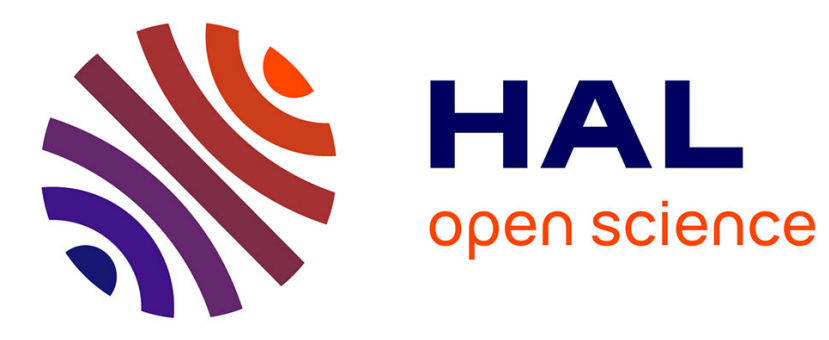

\title{
Working with Risk: Occupational Safety Issues among Health Care Workers in Kenya
}

Miriam Taegtmeyer, Ruth Suckling, Patrick Nguku, Caitlin Meredith, Josephine Kibaru, Jeremiah Muhwa Chakaya, Hadley Muchela, C. Gilks

\section{- To cite this version:}

Miriam Taegtmeyer, Ruth Suckling, Patrick Nguku, Caitlin Meredith, Josephine Kibaru, et al.. Working with Risk: Occupational Safety Issues among Health Care Workers in Kenya. AIDS Care, 2008, 20 (03), pp.304-310. 10.1080/09540120701583787 . hal-00513430

\author{
HAL Id: hal-00513430 \\ https://hal.science/hal-00513430
}

Submitted on 1 Sep 2010

HAL is a multi-disciplinary open access archive for the deposit and dissemination of scientific research documents, whether they are published or not. The documents may come from teaching and research institutions in France or abroad, or from public or private research centers.
L'archive ouverte pluridisciplinaire HAL, est destinée au dépôt et à la diffusion de documents scientifiques de niveau recherche, publiés ou non, émanant des établissements d'enseignement et de recherche français ou étrangers, des laboratoires publics ou privés. 

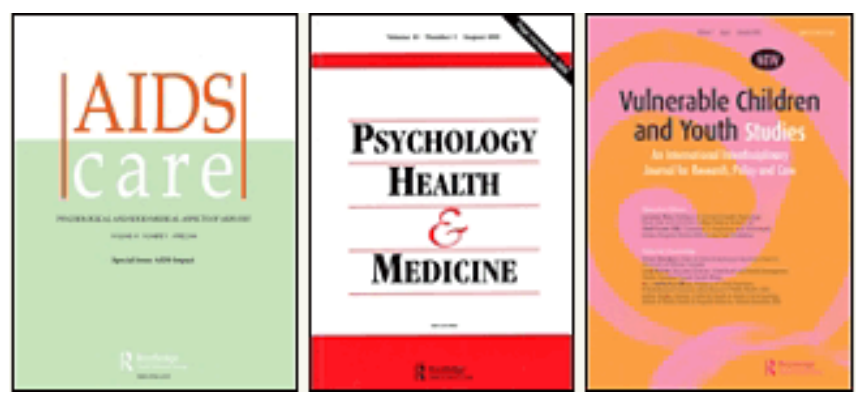

\section{Working with Risk: Occupational Safety Issues among Health Care Workers in Kenya}

\begin{tabular}{|r|l|}
\hline Journal: & $\begin{array}{l}\text { AIDS Care-Psychology, Health \& Medicine - Vulnerable Children } \\
\text { and Youth Studies }\end{array}$ \\
\hline Manuscript ID: & AC-2007-04-0145.R1 \\
\hline Journal Selection: & AIDS Care \\
\hline Keywords: & $\begin{array}{l}\text { HIV, occupational exposure, voluntary counselling and testing, post } \\
\text { exposure prophylaxis }\end{array}$ \\
\hline \multicolumn{2}{|l}{} \\
\hline
\end{tabular}

\section{S) ScholaronE \\ Manuscript Central}




\section{Introduction:}

In the last five years Kenya has seen a dramatic expansion of access to same-hour HIV testing (National AIDS and STD Control Programme, 2005) and substantial price decreases in antiretroviral therapy (ART) (UNAIDS, 2005). The rapid roll out of ART since mid 2004 means that health care workers in Kenya - who are at risk of contracting HIV at work - can now benefit from the availability of these drugs for post-exposure prophylaxis (PEP). In line with international guidelines and research (Mikulich \& Schriger, 2002; Cardo et al., 1997) the Kenyan Ministry of Health recommends PEP for staff who get a needlestick injury (National AIDS and STD Control Programme, 2004). In addition, a key indicator in the Kenyan Global Fund Strategy for HIV was 'to increase the number of rape victims and individuals with occupational injuries getting PEP from 0 in 2003 to 3,200 in 2005 (2003). However, when the strategy was drawn up it was unclear what the need for and uptake of PEP among health care workers might be. This paper documents experiences of PEP provision in a Kenyan district.

Occupational exposures to infection, although rarely reported, are common occurrences in resource-poor countries (Sagoe-Moses, Pearson, Perry, \& Jagger, 2001; Gounden YP, 2000; Mehta et al., 2005a), including Kenya. Adherence to occupational health guidelines is difficult in Kenya's public sector due to a lack of needle holders and the resulting presence of overflowing sharps bins and disposal pits. In addition, chronic understaffing is common, leading to a high turnover of short-term staff and poor knowledge of guidelines and policies. The high HIV sero-prevalence rates mean that increasing numbers of infectious carriers attend health care centres as patients (Arthur et al., 2000) and health care workers (HCWs) have justified concerns about the risk of 
accidental exposure. In recognition of this, staff receive a small monthly salary

supplementation in the form of a 'risk allowance'.

\section{Methods}

We conducted a five-phase study in a representative Kenyan health district employing

Deleted: to explore knowledge, attitudes and practice of post-exposure prophylaxis

650 staff and serving a population of approximately 660,000 people (Government of

Kenya, 2001). A summary of the methods may be seen in table 1 below. The study

combined quantitative and qualitative research methods (Hammersley, 1992),

Deleted: , using in-depth qualitative

Quantitative data were entered in Epi Info and Exel and analysed in Epi Info 2000.

Qualitative data were collected, recorded and transcribed by a single researcher with independent analysis by the principle investigator.

\section{Study site}

The study was conducted in Thika District, Kenya. With technical assistance from a Deleted: The district was selected for its existing services in voluntary counselling and testing for HIV (VCT) as well as it relationship with a local NGO: local NGO: Liverpool VCT, Treatment and Care in 2001 Thika became the first district in Kenya to integrate VCT into its government healthcare facilities, HIV seroLiverpool VCT and Care (LVCT)

Deleted: LVCT

Deleted: , providing access to rapid HIV testing for the general public and heath care staff prevalence rates in Thika reflected the national average between 10-15\% (Government of Kenya, 2004) with hospital inpatient HIV rates estimated at 50 70\% (Kibaru, 2002).

Deleted: to

The study was undertaken in 11 health facilities with VCT: 2 hospitals, 8 health centres and 1 dispensary. Mission hospitals, private clinics and small dispensaries were omitted, The study was designed collaboratively with the district health management team, including public health officers (responsible for bio-safety), physicians,

Deleted: the
Deleted: eleven
Deleted: two
Deleted: one
Deleted:
Deleted: which did not have established
VCT sites,
Deleted: from the study
counsellor supervisors, a public health nurse and the hospital matron. At the start of the study there was no provision of PEP or hepatitis B vaccination in the district. There was

Deleted: for 
no register of accidental exposures and no referral point for staff who wished to file a report. In early 2002 none of the private pharmacies in Thika district stocked antiretrovirals or hepatitis B vaccine.

\section{Bio-safety Survey (Phase 1: March-April 2002)}

An initial survey of sharps disposal practice was conducted in all 69 clinical areas of the 11 facilities.

\section{Baseline survey of knowledge, attitudes, practice and HIV sero-prevalence amongst}

Deleted: As well as discussion of safe injection technique and observation of disposal practice (process indicators) objective criteria such as sharps bins, pits, incinerators, guidelines and log books (infrastructure indicators) were scored on a checklist.II

\section{health care workers (Phase 2: March-August 2002)}

An interviewer-administered questionnaire was conducted in English and/or

Kiswahili. This included all HCWs involved in patient care, the laboratory or the disposal of waste. Staff were excluded if they were unable to speak English or Kiswahili, had been transferred out of the district, were on permanent night shifts or were absent for a period exceeding three months. Questions focused on knowledge of blood borne viruses and PEP and current biosafety practices, Recent occupational exposures reported through recall. High risk needlestick injuries were defined as deep injuries from hollow bore needles contaminated with blood or body fluids

Each staff member interviewed was asked to consent to serum being tested for HIV and hepatitis B using standard ELISA techniques. Hepatitis B test results were sent to the individuals concerned advising whether they needed vaccination. HIV testing was anonymous and unlinked. Healthcare workers wishing to know their HIV serostatus were advised to attend a VCT site for same-day testing.

Deleted: personnel and staff involved

Deleted: Staff lists were obtained from the District Medical Officer of Health and names of casual employees and student nurses were obtained from the departmental or health centre in-charges.

Deleted: knowledge of existing guidelines and current practices to minimize exposure

Deleted: The survey also assessed $r$

Deleted: in the preceding half hour. Respondents were also asked if they knew their HIV sero-status and whether they had used a local VCT centre for testing.

Deleted: for a serum sample to be drawn

Deleted: which was

Deleted: both

Deleted: Serum was tested in Kenya Medical Research Institute Virology lab Deleted: The results of the $\mathrm{h}$

Deleted: testing

Deleted: by letter

Deleted: and feedback was general

Deleted: where appropriate counselling and

Deleted: could be given 
Hepatitis B vaccine was made available through the existing cold chain for childhood immunisation without additional reminders or jncentives. Uptake of three doses was left to the staff and administration to their immediate colleagues.

HCWs were informed about PEP and the drugs were located in VCT sites. A twodrug PEP regime was chosen (Bassett, Freedberg, \& Walensky, 2004). The initial 6 doses were available at sites before referral the the district hospital where a clinician prescribed further treatment to those who had tested HIV negative, A full blood count, renal and liver function tests were done at 0,2 and 4 weeks and repeat HIV testing at 6 weeks and 3 months.

Purpose-made sharps bins and needle-holders were provided to each clinical area. Staff education and pit inspections by the district health management team were undertaken.

Quantitative and qualitative one-year follow-up (Phase 4: March-August 2003)

A repeat survey in the same clinical areas at one year included all HCWs in the district, whether or not they had previously completed the survey.

Group and individual in-depth interviews were utilized to explore barriers to PEP. HCWs were interviewed in mixed groups that were purposively sampled (Patton, 2002; Ritchie, Lewis, \& Elam, 2003). Semi-structured in depth individual interviews were conducted with key informants such as matrons, doctors and in-charges. Structured
Deleted: During the study period both hepatitis B vaccination and PEP were made available.

Deleted: at the health centres and hospitals

Deleted: other

Deleted: the

Deleted: of vaccine

Deleted: entirely

Deleted: and flowcharts provided. HIV nurse-counsellors were identified to be responsible for the appropriate use of PEP

Deleted: (a generic combination of Zidovudine and Lamivudine at standard adult dose for four weeks)

Deleted: for availability, cost and simplicity

Deleted: of treatment

Deleted: all

Deleted: and VCT-trained counsellors conducted rapid testing of the PEP recipients within 3 days of the exposure.

Deleted: after review of the baseline blood results

Deleted: During the intervention period feedback to the district health management team led to improvements in bio-safety, pit inspections and increased awareness about bio-safety.

Deleted: was done, including the printing of flow charts that were placed above the sharps bins. II

Deleted: At one year follow up there was a

Deleted: were included

Deleted: Staff lists were updated with information on staff transfers.

Deleted: used

Deleted: the uptake of 
topic guides were used to elicit information. Transcripts were analysed for similarities interviews and differences, drawing out common themes.

\section{Systems follow-up (Phase 5: August 2003 - August 2006)}

At the end of the study - a time of increasing access to generic antiretrovirals through the government system - the researchers and LVCT handed over the PEP and hepatitis $\underline{\mathrm{B} \text { administration systems to the district. Data on PEP uptake continued to be }}$ collected.

\section{Results}

The results are presented in the order of the study phases outlined and summarised in

Table 1. The statistical comparisons between the initial survey (phase two) and the one year follow-up (phase 3) are presented in table 2.

\section{Bio-safety survey and risk of occupational exposure}

Of the 69 clinical areas, none had copies of guidelines or universal precautions and none had reporting mechanisms for needlestick injuries. The use and supply of gloves was inconsistent - staff reported both double-gloving and running out of gloves. There was conflicting teaching on how to handle sharps, In some cases staff were

Deleted: t.

Deleted:

Deleted: , with

transferring sharps into disinfectant for 24 hours before disposal, thereby exposing themselves twice to potential injury. Only $26 \%$ percent of sharps bins were purposemade - staff were observed discarding contents in order to reuse them. Sixty-four percent of sharps bins were improvised out of old detergent bottles, moisturising cream or lard tubs and the remaining $10 \%$ were unsafe, including cardboard boxes and waste paper bins. All facilities had a covered placenta pit although only one third

Deleted: Deleted: however supplies were limited and Deleted: safely
Deleted: Further data were collected on PEP for occupational exposure were collected as part of a larger programme
on post-rape care in the district. This final phase was intended to look at policy and practice in the district without external research-driven support to assess longterm sustainability. II

Deleted:, with 
of facilities were disposing sharps into it with the remainder using an open pit. There were no functioning incinerators.

The annual incidence of needlestick injuries reported during the initial survey was 0.97 per health care worker per year, with $18 \%$ reporting a high-risk injury in the previous twelve months. Doctors, clinical officers and midwives had the highest rates of repeat injuries. At one-year follow up after instituting simple bio-safety measures, there was a significant reduction in high-risk injuries (OR 0.4, CI 0.25-0.6, p<0.001).

\section{Baseline knowledge, attitudes and practice; sero-prevalence of HIV and Hep B}

\section{(Phase 2)}

The total number of staff in the district was 650 with 496 permanent positions, 100

medical and nursing students and 54 casual labourers. Five hundred and fifty-four $(85 \%)$ staff answered the questionnaire, 72 were excluded and 24 declined interview.

Of interviewees, $78 \%$ were female and $63 \%$ were nurses,

Deleted: staff

Deleted: people

Deleted: to be interviewed

Deleted: , reflecting the make up of the district staff

Staff expressed concern about safety at work. Only $21 \%$ felt they had received adequate guidance in the workplace. Of those staff that had had a needlestick, $85 \%$ had taken appropriate first aid measures but only $14 \%$ reported the injury in the workplace; 2 people had taken PEP in the previous twelve months at their own expense. Knowledge of PEP was low $(23 \%)$ at baseline, in keeping with other resource-poor settings (Chogle NL, 2002). The survey also revealed significant concern among HCWs that PEP should be available for rape survivors. 
Four hundred and seven staff gave a blood sample for HIV and hepatitis serology (73\% of those completing the questionnaire) and they had similar ages and occupations to the 147 who did not give blood. There was no significant difference in the number of reported needlestick or sharps injuries or knowledge of HIV status, however, men (OR1.6, p=0.003) and previously vaccinated staff were less likely to give blood (OR 0.58; $\mathrm{p}=0.04)$ than their female and unvaccinated colleagues. Seven percent of staff who gave blood were HIV positive and $41 \%$ were hepatitis B core antibody positive. Staff are no more likely to be HIV or Hep B positive than the general population(Government of Kenya, 2004; Lule, Okoth, Ogutu, \& Mwai, 1989; Mwangi, 1999). The 93\% of staff who were HIV negative would benefit from PEP in the event of a needlestick if they knew their HIV status and chose to access PEP.

\section{Low uptake of PEP despite high uptake of Hepatitis B vaccine (phase 3)}

In the pre-intervention survey 530/554 (96\%) of respondents felt that they would want PEP to be available, Eighty-three percent (461/554) went so far as to state they were willing to forgo their risk allowance for PEP to be made available. However, despite 68 staff recalling that they had a NSI during the intervention year, the uptake of PEP was very low. During the interval year PEP protocols were commenced by only 3 workers (all female nurses) and completed by two of them. In contrast, 173 out of $222(78 \%)$ staff at risk of hepatitis B infection were self-motivated to attend for two or three doses Deleted: of of vaccine at 0, 1 and 6 months(Suckling et al., 2006).

\section{Improved knowledge of PEP and of HIV serostatus after one year (phase 4)}

At one year follow up 450 questionnaires were filled at 11 sites with similar staff demographics. Indicating a high turnover rate, 169 questionnaires were filled in by 
staff new to the district. Knowledge of PEP increased significantly, as did the number of HCWs who had had an HIV test in the previous twelve months (OR 1.55, CI 1.22.1, $\mathrm{p}=0.003)$ a majority of these having using the VCT site in their own place of work (91 out of 130).

Staff felt the low uptake of PEP was due to fear of testing (phase 4)

Deleted: When interviewed $s$

Insights from the qualitative data revealed that staff feared having an HIV test as they

Deleted: In the depth interviews staff were asked about the low uptake of PEP. were concerned about testing positive themselves. Despite knowing as a group they had relatively low rates $(7 \%)$ many staff felt unsure of their own status, Others were

Deleted: around Deleted: and preferred not to know concerned about confidentiality when testing at their own place of work. The following quotes reflect the sentiments of many staff:

Deleted: sum up

“If there wasn't the testing I can see that they will all take the PEP, because

they are not fearing" (female nurse, group interview, Thika)

and

"This VCT that insists you must be tested to get the PEP. People are worried about their privacy” (male clinical officer, individual interview, Thika)

Some were concerned that the knowledge of a positive status alone would make them

ill

"Once you discover you are HIV positive the word is that the immunity will still

drop lower..." (female nurse, individual interview, Thika)

Staff were also concerned about home life:

"If you are positive it will be said that you are unfaithful and maybe you get divorced." (female nurse, individual interview, Thika)

Many asked what the point of PEP in the workplace given that most HIV in Africa was transmitted sexually, In the words of this one woman:

Deleted: Some expressed a worry that they were more at risk of HIV at home than at work.

Deleted: was when

Deleted: and they were at risk sexually

Deleted: Some said they did not know their partner's status yet were continuing to have unprotected sex. 
"It is not easy to get it at work..at home is more of a risk. I am not trusting that husband at home." (female nurse, individual interview, Thika)

and

“And maybe the risk is too low from needle sticks...” (male clinical officer,

Deleted: ... individual interview, Thika)

\section{Staff all wanted PEP available (phase 4)}

Staff were asked whether PEP should be available despite the low uptake. The universal response of interviewees was yes. Various reasons were given, including the slow rate of behaviour change, time taken to accept and trust new services and the boost the availability of the service would give to staff morale. In the words of these staff:

"You have to have at least confidence, so you know where to run to in case you have a problem." (female nurse, individual interview, Thika)

"Yes (we still need PEP). Maybe the number might double by next year. Just like with VCT when we started. Before, the turnout wasn't good. Now we are overloaded." (female manager, individual interview, Thika)

\section{Monitoring on-going systems (phase 5)}

Since this study was conducted the Government of Kenya has been purchasing generic antiretrovirals through Global Fund support(2003)a regular clinic in Thika has been established for the distribution of antiretrovirals and the district became a referral point for the treatment of rape survivors, During the time period (August 2003 - August 2006) 23 requests for PEP for NSI and 251 for post-rape PEP were seen. No further hepatitis B vaccine was purchased or administered due to the lack of central purchasing, and lack of continuity among District Medical Officers of Health.

Deleted: $\mathrm{T}$

Deleted: is

Deleted: and

Deleted: the district laboratory are waiving fees for monitoring blood tests. A

Deleted: of sexual assault 


\section{Discussion}

At the time this study was initiated Thika was a representative district on the brink of an

antiretroviral treatment programme for HIV-positive patients. Operational research

conducted in this setting provides information relevant for national policies on

needlestick injuries and PEP provision.

As previously described, bio-safety education and materials remain the most

Deleted: remains significant intervention through reducing the number of needlestick incidents_(Bell, 1991). The baseline rates in this study are comparable to those among HCWs in other resource-poor settings and greater than in resource-rich countries_(Kosgeroglu N, 2004; Mehta et al., 2005b; Longbottom, Cox, \& Sokas, 1993; Newsom \& Kiwanuka, 2002; Talaat et al., 2003; Turner, Hurley, Butler, \& Holl, 1999). Simple interventions such as supply of needle-holders, sharps bins and appropriate and adequately safe local solutions (use of improvised sharps bins, use of placenta pits) led to a significant reduction in sharps injuries at one year follow up. The involvement of the District Health Management Team means these changes are likely to be sustained.

Staff are concerned about health and safety at work and value interventions that protect them. Eighty-five percent of all HCWs in the district took part in the study and $73 \%$ of these gave serum for testing. While women were more likely to give blood than men, staff of both genders were initially reluctant to give blood. Pre-employment screening for HIV is not conducted in Kenya and there is considerable anxiety amongst HCWs that blood testing of any sort could lead to limitations of employment. The high rates of participation may reflect staff concerns about their health, the 
incentive of free vaccination and the perceived trustworthiness of the researchers.

They also reflect ownership of the study with the district health management team and departmental in-charges. The uptake of hepatitis B vaccine_(Suckling et al., 2006) demonstrates that staff will take up interventions that are familiar, free and efficacious, even if it means going out of their way to do so. Given the rates of occupational exposure it was not surprising to see a high demand for a PEP referral point,

Deleted: that Deleted: staff expressed concern and that

Deleted: for PEP was high Deleted: Even staff who had not accessed PEP after a needlestick wanted it to be available in the district.

The fear and stigma associated with HIV testing remain a barrier to PEP programmes Deleted: of that will take time to overcome, even in the presence of focused efforts to address them. The use of local VCT centres by HCWs in our study was encouraging. The Deleted: This significant increase in HCWs who attended VCT near or at their place of work in the year of the intervention indicate that instilling confidence in local testing services may be one way of addressing this issue. Staff who already know they are HIV negative might be more likely to opt for PEP and thus maintain their negative status than those who do not know. The HCWs reported that the PEP programme made them feel valued indicating it may have had a positive influence on morale as well as stigma reduction in the hospital environment.

District implementation of PEP is sustainable in the context of a larger ARV programme. PEP, following both occupational and non-occupational exposure, is now increasingly linked to existing HIV ART and post-rape care services(National AIDS and STD Control Programme, 2005). This allows for a focal point for occupational PEP to which even private and mission hospitals are able to refer. A district riskreduction plan and the development of an annual training package would provide 
other practical points for implementation as well as pre-service training before students are sent on clinical attachments. The availability of PEP for occupational exposure in a district would also form a stepping stone to link to services required in comprehensive post rape care. The strengthening of government systems - reflecting national and international commitment to improved access to ART _ has simplified systems for PEP. However, uptake was still lower than might be predicted from the number of needlestick injuries reported in previous years in keeping with similar reports from neighbouring countries(van Oosterhout et al., 2007). More needs to be done both to encourage staff to know their HIV serostatus and to make systems as user-friendly as possible in health centres where there are no ART clinics.

\section{Conclusion:}

$\underline{\text { The rapid global scale-up of access to antiretroviral therapy (ART) for HIV means that }}$ HCWs at risk of contracting HIV at work in Sub-Saharan Africa, can now benefit from the availability of PEP. While the fear of HIV testing is a significant barrier to PEP programmes this can be overcome if there is universal access to HIV testing that HCWs have confidence in along with on-going ART programmes. HCWs are concerned about their health and value interventions that reduce occupational exposure to infection. access to antiretroviral therapy (ART) for
HIV means that HCWs in Sub-Saharan
Africa, who are at risk of contracting HIV
at work, can now benefit from the
availability of PEP. HCWS are concerned
about their health and value interventions
that reduce occupational exposure to
infection. While the fear of HIV testing is
a significant barrier to PEP programmes
this can be overcome if there is universal
access to HIV testing that HCWs have
confidence in and in the context of on-
going ART programmes. II 


\section{Acknowledgements}

This paper is published with the kind permission of the Director of KEMRI (Kenya Medical Research Institute). We are grateful to the District Health Management Team and staff of Thika district in Kenya and also to Nduku Kilonzo, Eunice Kuria, Charity Mbugua and Drs Colin Speight and Anthea Klufio who were involved in the running and data collection for phase 5 of follow-up. We would like to thank Dr Peter Tukei and the laboratory technologists of the KEMRI Centre for Virology Research.

Ethical Approval: Ethical Review Board of the Kenya Medical Research Institute (KEMRI) Funding

The HIV/AIDS Knowledge Programme, Liverpool School of Tropical Medicine (LSTM) is a collaborative programme funded by DFID (Department For International Development) to develop 'knowledge for action' in the field of HIV/AIDS prevention and care and funded Dr Suckling's salary for 8 months. Tulane University funded Caitlin Meredith's internship. 


\section{Reference List}

Arthur, G., Bhatt, SM., Muhindi, D., Achiya, G., Kariuki, SM., \& Ginwalla, S. K. (287-2000). The changing impact of HIV/AIDS on Kenyatta National Hospital, Nairobi from 1988/89 through 1992 to 1997. AIDS 14[11], 1625-1632.

Bassett, I. V., Freedberg, K. A., \& Walensky, R. P. (2004). Two drugs or three? Balancing efficacy, toxicity, and resistance in postexposure prophylaxis for occupational exposure to HIV. Clinical Infectious Diseases, 39, 395-401.

Bell, D. M. (1991). Human immunodeficiency virus transmission in health care settings: risk and risk reduction. American Journal of Medicine, 91, 294S-300S.

Cardo, D. M., Culver, D. H., Ciesielski, C. A., Srivastava, P. U., Marcus, R., Abiteboul, D. et al. (1997). A case-control study of HIV seroconversion in health care workers after percutaneous exposure. Centers for Disease Control and Prevention Needlestick Surveillance Group. NEJM, 337, 1485-1490.

Chogle NL, C. M. D. J. D. D. (2002). Awareness of post-exposure prophylaxis guidelines against occupational exposure to HIV in a Mumbai hospital. Natl Med J India 5[15], 69-72.

Global Fund to Fight AIDS, Tuberculosis and Malaria (2003). Available on line at http://www.theglobalfund.org/en/ accessed on $10^{\text {th }}$ August 2004

Gounden YP, M. J. (1-6-2000). Exposure to human immunodeficiency virus among healthcare workers in South Africa. Int J Gynaecol Obstet 3[69], 265-270. 
Government of Kenya. (2001). Analytic Report of the Central Bureau of Statistics, Ministry of Planning and National Development, Central Bureau of Statistics, Nairobi Government of Kenya (2003). Demographic Health Survey. Ministry of Planning and National Development, Central Bureau of Statistics, Nairobi

Hammersley, M. (1992). Deconstructing the qualitative-quantitative divide. In J.Brannen (Ed.), Mixing Methods: Qualitative and Quantitative Research (pp. 39-55). Avebury: Aldershot.

Kibaru, J. District Medical Officer of Health Personal Communication $15^{\text {th }}$ Jan 2002

Kosgeroglu N, A. U. V. E. D. S. (2004). Occupational exposure to hepatitis infection among Turkish nurses: frequency of needle exposure, sharps injuries and vaccination. Epidemiology and Infection 1[132], 27-33.

Longbottom, H. M., Cox, K., \& Sokas, R. K. (1993). Body fluid exposure in an urban tertiary care medical center. Am J Ind Med, 23, 703-710.

Lule, G. N., Okoth, F., Ogutu, E. O., \& Mwai, S. J. (1989). HBV markers in 160 medical students at Kenyatta National Hospital. East Afr Med J, 66, 315-318.

Mehta, A., Rodrigues, C., Ghag, S., Bavi, P., Shenai, S., \& Dastur, F. (2005).

Needlestick injuries in a tertiary care centre in Mumbai, India. J Hosp Infec, 60, 368373.

Mikulich, V. J. \& Schriger, D. L. (2002). Abridged version of the updated US Public Health Service guidelines for the management of occupational exposures to hepatitis B 
virus, hepatitis $\mathrm{C}$ virus, and human immunodeficiency virus and recommendations for postexposure prophylaxis. Annals of Emergency Medicine, 39, 321-328.

Mwangi, J. W. (1999). Viral Markers in a Blood Donor Population. East Afr Med J, 76, 35-37.

National AIDS and STD Control Programme (2004). Kenyan National ARV Guidelines Nairobi: Ministry of Health.

National AIDS and STD Control Programme, M. o. H. K. (2005). AIDS in Kenya:

Trends, Interventions and Impact. (7th ed.) Nairobi: National AIDS and STD Control Programme

Newsom, D. H. \& Kiwanuka, J. P. (2002). Needlestick Injuries in a Ugandan Teaching Hospital. Ann Trop Med Parasitol, 96, 517-522.

Patton, M. (2002). Qualitative Research and Evaluation Methods. (Third edition)

London: Sage Publications Inc.

Ritchie, J., Lewis, J., \& Elam, G. (2003). Designing and selecting samples. In J.Ritchie \& J. Lewis (Eds.), Qualitative Research Practice: a guide for social science students and researchers (pp. 77-108). London: Sage Publications Inc.

Sagoe-Moses, C., Pearson, R. D., Perry, J., \& Jagger, J. (16-8-2001). Risks to Health Care Workers in Developing Countries. NEJM 345[7], 538-541.

Suckling, R. M., Taegtmeyer, M., Nguku, P. M., Al-Abri, S. S., Kibaru, J., Chakaya, J. M. et al. (2006). Susceptibility of healthcare workers in Kenya to hepatitis B: new strategies for facilitating vaccination uptake. J Hosp Infec, 64, 271-277. 
Talaat, M., Kandeel, A., El Shoubary, W., Bodenschatz, C., Khairy, I., Oun, S. et al. (2003). Occupational exposure to needlestick injuries and hepatitis B vaccination coverage among health care workers in Egypt. Am J Infect Control, 31, 469-474.

Turner, H. S., Hurley, J. L., Butler, K. M., \& Holl, J. (1999). Accidental exposures to blood and other body fluids in a large academic medical center. Journal of American College Health, 47, 199-206.

UNAIDS (2005). "Treat 3 million by 2005" (3 by 5) Initiative. Available on line at http://www.unaids.org/en/treat+3+million+by+2005+initiative.asp. Accessed on $10^{\text {th }}$ August 2004

van Oosterhout, J. J., Nyirenda, M., Beadsworth, M. B., Kanyangalika, J. K., Kumwenda, J. J., \& Zijlstra, E. E. (2007). Challenges in HIV post-exposure prophylaxis for occupational injuries in a large teaching hospital in Malawi. Trop Doct., 37, 4-6. 


\section{Table 1: Summary of methodology and timescale of study}

\begin{tabular}{|c|c|c|c|c|c|c|}
\hline & Phase 1 & Phase 2 & Phase 3 & Phase 4a & Phase $4 b$ & Phase 5 \\
\hline Objective & $\begin{array}{l}\text { Baseline } \\
\text { bio-safety }\end{array}$ & $\begin{array}{l}\text { Baseline } \\
\text { survey and } \\
\text { sero- } \\
\text { prevalence }\end{array}$ & $\begin{array}{l}\text { Intervention; } \\
\text { provision of } \\
\text { biosafety, } \\
\text { PEP and } \\
\text { Hep B } \\
\text { vaccine }\end{array}$ & $\begin{array}{l}\text { Follow-up } \\
\text { Survey }\end{array}$ & $\begin{array}{l}\text { Qualitative } \\
\text { exploration }\end{array}$ & $\begin{array}{l}\text { Health } \\
\text { Systems } \\
\text { monitoring }\end{array}$ \\
\hline Dates & $\begin{array}{l}\text { Mar 2002 - } \\
\text { Apr } 2002\end{array}$ & $\begin{array}{l}\text { Mar 2002 - } \\
\text { Aug } 2002\end{array}$ & $\begin{array}{l}\text { May } 2002 \text { - } \\
\text { Aug2003 }\end{array}$ & $\begin{array}{l}\text { Mar 2003 - } \\
\text { Aug } 2003\end{array}$ & July 2003 & $\begin{array}{l}\text { Aug } 2003 \text { - } \\
\text { Aug } 2004\end{array}$ \\
\hline Design & Survey & Survey & $\begin{array}{l}\text { Operational } \\
\text { research }\end{array}$ & Survey & $\begin{array}{l}\text { Group and } \\
\text { in-depth } \\
\text { individual } \\
\text { interviews }\end{array}$ & \\
\hline Sampling & $\begin{array}{l}\text { All govt. } \\
\text { health care } \\
\text { centres and } \\
\text { hospitals }\end{array}$ & $\begin{array}{l}\text { All HCWs in } \\
\text { Thika district }\end{array}$ & $\begin{array}{l}\text { All HCWs } \\
\text { requiring } \\
\text { vaccine or } \\
\text { HIV PEP }\end{array}$ & $\begin{array}{l}\text { HCWs in } \\
\text { Thika } \\
\text { District }\end{array}$ & $\begin{array}{l}\text { Purposive } \\
\text { sampling } \\
\text { of HCWs } \\
\text { and key } \\
\text { informants }\end{array}$ & $\begin{array}{l}\text { All HCWs in } \\
\text { Thika district }\end{array}$ \\
\hline Participants & $\begin{array}{l}11 \text { health } \\
\text { facilities }\end{array}$ & $\begin{array}{l}\text { HCWs in } \\
\text { Thika district }\end{array}$ & $\begin{array}{l}\text { HCWs in } \\
\text { Thika } \\
\text { district }\end{array}$ & $\begin{array}{l}\text { HCWs in } \\
\text { Thika } \\
\text { district }\end{array}$ & $\begin{array}{l}4 \text { group } \\
\text { interviews } \\
11 \\
\text { individual } \\
\text { interviews }\end{array}$ & $\begin{array}{l}\text { All HCWs in } \\
\text { Thika district }\end{array}$ \\
\hline $\begin{array}{l}\text { Outcome } \\
\text { Measures }\end{array}$ & $\begin{array}{l}\text { Bio-safety } \\
\text { standards in } \\
\text { clinical areas }\end{array}$ & $\begin{array}{l}\text { Knowledge, } \\
\text { attitudes and } \\
\text { practice re: } \\
\text { occupational } \\
\text { exposure. } \\
\text { Baseline HIV } \\
\text { prevalence in } \\
\text { HCWs }\end{array}$ & $\begin{array}{l}\text { Uptake of } \\
\text { PEP } \\
\text { compared } \\
\text { with uptake } \\
\text { of Hepatitis } \\
\text { vaccination }\end{array}$ & $\begin{array}{l}\text { Changes in } \\
\text { knowledge, } \\
\text { attitudes and } \\
\text { practice re: } \\
\text { occupational } \\
\text { exposure }\end{array}$ & $\begin{array}{l}\text { Reasons } \\
\text { for uptake } \\
\text { elucidated }\end{array}$ & $\begin{array}{l}\text { Sustainability } \\
\text { indicators }\end{array}$ \\
\hline
\end{tabular}


Table 2: Comparison of knowledge, attitudes and practice amongst Thika district health care workers at baseline and at one year

\begin{tabular}{|c|c|c|c|c|c|c|c|}
\hline \multirow[t]{2}{*}{ Factor } & \multicolumn{2}{|l|}{$\begin{array}{l}\text { Baseline } \\
\text { (554) }\end{array}$} & \multicolumn{2}{|c|}{$\begin{array}{l}\text { One year } \\
(450)\end{array}$} & \multirow[t]{2}{*}{ OR* } & \multirow[t]{2}{*}{ CI } & \multirow[t]{2}{*}{ p value } \\
\hline & & $\%$ & & $\%$ & & & \\
\hline $\begin{array}{l}\text { Workplace } \\
\text { guidance was } \\
\text { adequate }\end{array}$ & $116 / 554$ & 21 & $293 / 448$ & 65 & 9.6 & $7.1,13.1$ & $<0.001$ \\
\hline $\begin{array}{l}\text { Any exposure } \\
\text { in last } 12 \\
\text { months }\end{array}$ & $167 / 554$ & 30 & $68 / 450$ & 15 & 0.4 & $0.3,0.6$ & $<0.001$ \\
\hline $\begin{array}{l}\text { High risk } \\
\text { exposure in last } \\
12 \text { months }\end{array}$ & $115 / 554$ & 21 & $40 / 450$ & 9 & 0.4 & $0.25,0.6$ & $<0.001$ \\
\hline $\begin{array}{l}\text { Appropriate } \\
\text { first aid after } \\
\text { NSI in last } 12 \\
\text { months }\end{array}$ & $142 / 167$ & 85 & $55 / 68$ & 81 & 0.7 & $0.3,1.7$ & 0.43 \\
\hline $\begin{array}{l}\text { Exposures in } \\
\text { last } 12 \text { months } \\
\text { reported in the } \\
\text { workplace }\end{array}$ & $23 / 167$ & 14 & $16 / 68$ & 23 & 1.9 & $0.9,4.2$ & 0.07 \\
\hline $\begin{array}{l}\text { Hep B vaccine } \\
\text { up to date }\end{array}$ & $22 / 554$ & 4 & $175 / 450$ & 39 & 15 & $9.5,25.3$ & $<0.001$ \\
\hline Hep B core Ab & $167 / 407$ & 41 & N/A & - & & & \\
\hline HIV positive & $29 / 407$ & 7 & N/A & & & & \\
\hline $\begin{array}{l}\text { Had HIV test } \\
\text { ever }\end{array}$ & $180 / 554$ & 32 & $202 / 450$ & 45 & 1.7 & $1.3,2.2$ & $<0.001$ \\
\hline $\begin{array}{l}\text { HIV test last } 12 \\
\text { months }\end{array}$ & $115 / 554$ & 21 & $130 / 450$ & 29 & 1.55 & $1.2,2.1$ & 0.003 \\
\hline $\begin{array}{l}\text { Had HIV test at } \\
\text { local VCT } \\
\text { centre }\end{array}$ & $74 / 554$ & 13 & $91 / 450$ & 20 & 1.64 & $1.2,2.3$ & 0.004 \\
\hline $\begin{array}{l}\text { Knowledge of } \\
\text { PEP }\end{array}$ & $126 / 554$ & 23 & $341 / 448$ & 76 & 10.8 & $8.0,14.7$ & $<0.001$ \\
\hline $\begin{array}{l}\text { Taken PEP for } \\
\text { NSI in last } 12 \\
\text { months }\end{array}$ & $2 / 167$ & 1 & $3 / 68$ & 4 & 3.8 & $0.5,33.5$ & 0.12 \\
\hline
\end{tabular}

$* \mathrm{OR}=$ Odds Ratio for the differences found at one year follow-up, given the value of the variable. An Odds Ratio $>1$ indicates an increase after the intervention and an Odds Ratio $<1$ indicates a decline after the intervention. The reference value for variables is given in the denominator of the proportions. 